\title{
A DEFECT IN THE METABOLISM OF TYROSINE AND PHENYLAL- ANINE IN PREMATURE INFANTS. I. IDENTIFICATION AND ASSAY OF INTERMEDIARY PRODUCTS ${ }^{1,2}$
}

\author{
BY S. Z. LEVINE, ELEANOR MARPLES, AND HARRY H. GORDON \\ (From the Neiv York Hospital and the Department of Pediatrics, Cornell University Medical \\ College, New York City)
}

(Received for publication October 24, 1940)

In the course of studies of the urinary excretion of creatinine by premature infants, a number of the infants fed cow's milk were found to excrete a substance which gave the Jaffe reaction but which was not creatinine. The interfering chromogen was differentiated from creatinine by its solubility in ether, its lack of adsorption by Lloyd's reagent and its partial destruction by heat $\left(100^{\circ} \mathrm{C}\right.$.) in acid solution. It also gave a yellow color with dinitrobenzoic acid in alkaline solution instead of the purple-rose color given by creatinine (1). Acetone and acetoacetic acid were not present in the urines. This chance discovery initiated the present studies.

The fact that the chromogen appeared only in the urine of infants receiving cow's milk diets relatively high in protein ( 5 grams or more per $\mathrm{kgm}$.) suggested that it might be an intermediary product of protein metabolism. Qualitative and quantitative (2) tests of chromogenic urines revealed usual amounts of amino acids. Qualitative tests for tryptophane and the indole ring were negative. The Millon test for the hydroxyphenyl group was strongly positive, indicating that the intermediary products in the urine were probably derived from the metabolism of tyrosine and possibly of phenylalanine, an hypothesis which was substantiated by feeding observations with pure amino acids. The absence of darkening of the urine during aeration excluded the presence of significant amounts of homogentisic acid (alkaptonuria).

Isolation and identification of intermediary metabolites

Identification of the unknown substances was made by Dr. Hans T. Clarke. From an ether extract of acidi-

\footnotetext{
1 Presented in part at the meeting of the American Pediatric Society at Skytop, Pa., on May 3, 1940.

2 Assistance in this work was given by the Children's Bureau, U. S. Department of Labor.
}

fied urine, he isolated $p$-hydroxyphenyllactic acid in the form of colorless needles melting at $169-170^{\circ}$. These crystals, which dissolved fairly readily in hot water, showed $[\alpha]_{\mathrm{D}}^{23}-16.1^{\circ}$. Combustion analysis gave C 56.27, H 5.80; calculated for $\mathrm{C}_{1} \mathrm{H}_{10} \mathrm{O}_{4} \cdot \frac{1}{2} \mathrm{H}_{2} \mathrm{O}: \mathrm{C} 56.54$, $\mathrm{H}$ 5.76. A sample of the crystals, dried in vacuo over $\mathrm{P}_{2} \mathrm{O}_{8}$ for 8 hours at $110^{\circ}$ lost 22.9 per cent of its weight; on further treatment under these conditions for 2 hours the loss had increased to 24.5 per cent, indicating that part of the loss was probably due to volatilization. The residue, which was undoubtedly anhydrous, gave on combustion: $\mathrm{C} 59.31, \mathrm{H} 5.69$; calculated for $\mathrm{C}_{0} \mathrm{H}_{10} \mathrm{O}_{4}$ : C 59.34, H 5.49 .

The presence of 1-p-hydroxyphenyllactic acid in chromogenic urines was thus established. That it was not the only abnormal constituent present was indicated by the fact that pure p-hydroxyphenyllactic acid did not give the following reactions characteristic of these urines: (1) a positive Jaffe reaction, (2) a precipitate with 2:4-dinitrophenylhydrazine and (3) reduction of phosphomolybdic acid.

These tests indicated the presence of a carbonyl derivative. Derivatives of this nature, particularly $p$-hydroxyphenylpyruvic and phenylpyruvic acids, are recognized intermediary products in the metabolism of tyrosine and phenylalanine. Kotake et al (3) and Lewis et al (4) identified these acids in the urine of animals fed these amino acids and the latter authors (4a) reported that phenylpyruvic acid gives the Jaffe reaction. Medes (5) reported the excretion of $p$-hydroxyphenylpyruvic acid by a man suffering from a metabolic defect to which she gave the name "tyrosinosis."

Attempts to isolate these acids directly, or as their 2:4-dinitrophenylhydrazones, were unsuccessful. By means of the Knoop reaction with palladium as the catalyst, Dr. Clarke was able to convert the $p$-hydroxyphenylpyruvic acid in the residue of an ethereal extract of acidified urine into $d, 1$-tyrosine, thus establishing the presence of the keto acid in the original urine. The residue from the Knoop reaction contained only traces of phenylalanine, indicating the presence of relatively minute amounts of phenylpyruvic acid in the original urine. The virtual absence of phenyllactic acid in these urines was established by means of Block's modification of the Kapeller-Adler method (6). ${ }^{3}$

${ }^{8}$ We are indebted to Dr. Hans T. Clarke and his colleagues, Dr. R. J. Block and Dr. Sarah Ratner, for these analyses. 
Dr. K. Dobriner, to whom we are also indebted, confirmed spectroscopically the presence in these urines of $p$-hydroxyphenylpyruvic acid (bands in region: 2900 to $3250 \mathrm{~A}^{\circ}$ ) and either $p$-hydroxyphenyllactic or $p$-hydroxyphenylacetic acids. Differentiation of the latter two acids could not be made by spectroscopic means since their absorption bands are practically identical (bands in regions : 2780 to $2820 \mathrm{~A}^{\circ}$ and 2860 to $2890 \mathrm{~A}^{\circ}$ ). Appropriately treated urines never showed the absorption bands characteristic of benzoic, hippuric, phenylpyruvic or homogentisic acids.

\section{Quantitative assay of intermediary metabolites}

Following identification of the abnormal constituents in the urine as $p$-hydroxyphenylpyruvic and $p$-hydroxyphenyllactic acids, suitable methods were elaborated for their quantitative determination. Total hydroxyphenyl compounds (tyrosine, $p$-hydroxyphenyllactic and $p$ hydroxyphenylpyruvic acids), expressed as tyrosine equivalent, were determined by the Folin and Ciocalteu (7) method as modified by Medes (5). The urine, made weakly acid with acetic acid, was shaken with Lloyd's reagent (1.5 grams per $100 \mathrm{cc}$. urine) (8) to remove coloring matter and impurities capable of reacting with mercuric sulfate in subsequent procedures. An aliquot of the filtrate containing the equivalent of 0.15 to 0.50 mgm. tyrosine was treated with mercuric sulfate as outlined by Medes (5). Comparison of color was made either in a colorimeter against a standard containing $\mathbf{0 . 5}$ mgm. tyrosine or in an Evelyn photoelectric colorimeter which had been standardized with pure tyrosine solutions of known concentration.

The results could be expressed in terms of total tyrosine equivalent since equimols of $p$-hydroxyphenylpyruvic and $p$-hydroxyphenyllactic acids gave the same intensity of color as tyrosine. The rate of color development differed, however, in the three compounds. Whereas the maximum color developed by $p$-hydroxyphenylpyruvic acid was attained approximately 20 minutes after the addition of sodium nitrite, it appeared almost immediately with tyrosine and $p$-hydroxyphenyllactic acid and remained practically unchanged during the succeeding 20 minutes. Readings were therefore made exactly 20 minutes after addition of the sodium nitrite. 4

Reduction of phosphomolybdic acid in acid solution as given by Medes (5) was used for the determination of $p$-hydroxyphenylpyruvic acid. Preliminary treatment of the urine with Lloyd's reagent was carried out as outlined above. In the early part of the work, a hydroquinone

\footnotetext{
4 This procedure was followed except in instances when the output of total hydroxyphenyl compounds (expressed as tyrosine) was less than $\mathbf{5 0} \mathbf{m g m}$. per 24 hours, a level arbitrarily regarded as insignificant. Under these conditions, the required use of a volume of urine in excess of 0.5 cc. resulted in the development of turbidity on standing for 20 minutes. The time of readings in these instances was reduced to one minute after addition of the sodium nitrite.
}

standard was used for colorimetric comparison. Under the experimental conditions, $1 \mathrm{mgm}$. of hydroquinone was found to be equivalent to $0.3 \mathrm{mgm}$. p-hydroxyphenylpyruvic acid. In later work, readings were made with the Evelyn photoelectric colorimeter, using as a standard of reference a curve prepared with solutions of pure $p$-hydroxyphenylpyruvic acid of known concentration. The pure acid was prepared by the method of Herbst and Shemin (9). The method as given is non-specific but it was found that the urines contained practically no other substances capable of reducing phosphomolybdic acid in acid solution. Normal urine, as well as urine following removal of $p$-hydroxyphenylpyruvic acid by ether extraction, gave values equivalent to less than 5 mgm. p-hydroxypyhenylpyruvic acid per 100 cc. Homogentisic acid, which gives this reaction, was excluded by repeated qualitative tests.

The difference between the total hydroxyphenyl compounds (expressed as tyrosine) determined by the Millon reaction $(5,7)$, and the keto acid determined by the reduction of phosphomolybdic acid (5), afforded a quantitative measure of $p$-hydroxyphenyllactic acid, since the urinary excretion of tyrosine per se remained a relatively constant and insignificant quantity ${ }^{5}$ and since other phenolic derivatives were not present in the urine in significant amounts.

Total nitrogen was determined by the macro-Kjeldahl method; amino acid nitrogen by Folin's (2) colorimetric method; organic acids by the method of Van Slyke and Palmer (10) and creatine and creatinine by the Folin method (11). Free and total phenols were estimated by the method of Folin and Denis (12). This procedure was later abandoned when it was found that pure $p$ hydroxyphenylpyruvic acid gave irregular values far in excess of its theoretical phenol content. Lewis and his coworkers (4a) have reported similar inconsistencies for phenylpyruvic acid with this method (12).

\section{RESULTS}

\section{Relation of protein intake to excretion of hydroxyphenyl compounds}

A typical example of the defect in the metabolism of tyrosine and phenylalanine of premature infants is presented in Table $I$. This infant excreted minimal amounts of hydroxyphenyl compounds when he was receiving human milk with a protein intake of 2.3 grams per kgm. per day

${ }^{5}$ On a number of occasions, tyrosine was determined by the Folin and Ciocalteu (7) method following removal of $p$-hydroxyphenyllactic and $p$-hydroxyphenylpyruvic acids from the urine by extraction with ether. Routine resort to this procedure was unnecessary since the content of tyrosine, when determined, was always less than $25 \mathrm{mgm}$. per $100 \mathrm{cc}$. urine (or $50 \mathrm{mgm}$. per 24 hours) in the premature infants studied, whether the diet consisted of human or cow's milk. 
TABLE I

Effect of protein intake on urinary excretion of hydroxyphenyl compounds

\begin{tabular}{|c|c|c|c|c|c|c|c|c|c|c|c|c|c|}
\hline \multirow{3}{*}{ Age } & \multirow{3}{*}{ Weight } & \multirow{3}{*}{ Diet } & \multirow{3}{*}{\begin{tabular}{|} 
Nitrogen \\
intake
\end{tabular}} & \multicolumn{10}{|c|}{ Urine } \\
\hline & & & & \multirow{2}{*}{$\begin{array}{c}\text { Total } \\
\text { urine } \\
N\end{array}$} & \multirow{2}{*}{$\underset{\text { nine }}{\text { Creati- }}$} & \multirow{2}{*}{$\begin{array}{c}\text { Crea- } \\
\text { tine }\end{array}$} & \multirow{2}{*}{$\begin{array}{c}\text { Amino } \\
\text { acid }\end{array}$} & \multirow{2}{*}{$\underset{\text { acids }}{\text { Organic }}$} & \multicolumn{2}{|c|}{ Phenols } & \multirow{2}{*}{$\begin{array}{c}\text { Total } \\
\text { hydroxy- } \\
\text { phenyl } \\
\text { compounds } \\
\text { expressed } \\
\text { as tyrosine }\end{array}$} & \multirow{2}{*}{$\begin{array}{c}p \text {-Hydroxy- } \\
\text { phenyl- } \\
\text { pyruvic } \\
\text { acid }\end{array}$} & \multirow{2}{*}{$\begin{array}{c}p \text {-Hydroxy } \\
\text { phenyl- } \\
\text { lactic } \\
\text { acid and } \\
\text { tyrosine* }\end{array}$} \\
\hline & & & & & & & & & Free & $\begin{array}{l}\text { Conju- } \\
\text { gated }\end{array}$ & & & \\
\hline days & kgm. & & $\begin{array}{l}\text { mgm. per } \\
\text { kgm. per } \\
\text { 24 hours }\end{array}$ & \multicolumn{4}{|c|}{ mgm. $N$ per $\mathrm{kgm}$. per 24 hours } & $\begin{array}{l}\text { cc. N/10 } \\
\text { per kgm. } \\
\text { per } 24 \\
\text { hours }\end{array}$ & \multicolumn{5}{|c|}{ milligrams per 24 hours } \\
\hline $\begin{array}{l}10 \\
11 \\
12 \\
13 \\
14\end{array}$ & $\begin{array}{l}1.95 \\
1.98 \\
1.99 \\
2.03 \\
2.06\end{array}$ & $\begin{array}{c}\text { Human milk } \\
\text { Cow's milk } \\
\text { Cow's milk } \\
\text { Cow's milk } \\
\text { Cow's milk }\end{array}$ & $\begin{array}{l}366 \\
764 \\
838 \\
823 \\
811\end{array}$ & $\begin{array}{r}66 \\
103 \\
184 \\
247 \\
297\end{array}$ & $\begin{array}{l}3.5 \\
4.3 \\
4.5 \\
4.8 \\
4.8\end{array}$ & $\begin{array}{l}0.2 \\
0 \\
0.1 \\
0.1 \\
0.1\end{array}$ & $\begin{array}{r}7 \\
9 \\
10 \\
10 \\
10\end{array}$ & $\begin{array}{l}37 \\
46 \\
47 \\
57 \\
58\end{array}$ & $\begin{array}{r}9 \\
12 \\
22 \\
32 \\
31\end{array}$ & $\begin{array}{l}4 \\
6 \\
6 \\
4 \\
5\end{array}$ & $\begin{array}{l}12 \\
17 \\
40 \\
62 \\
63\end{array}$ & $\begin{array}{r}3 \\
4 \\
8 \\
12 \\
13\end{array}$ & $\begin{array}{r}9 \\
13 \\
32 \\
50 \\
50\end{array}$ \\
\hline $\begin{array}{l}17 \\
18 \\
19 \\
20 \\
21\end{array}$ & $\begin{array}{l}2.17 \\
2.23 \\
2.26 \\
2.27 \\
2.28\end{array}$ & $\begin{array}{l}\text { Cow's milk } \\
\text { Cow's milk } \\
\text { Cow's milk } \\
\text { Cow's milk } \\
\text { Cow's milk }\end{array}$ & $\begin{array}{l}852 \\
831 \\
820 \\
816 \\
812\end{array}$ & $\begin{array}{l}384 \\
413 \\
476 \\
490 \\
440\end{array}$ & $\begin{array}{l}4.8 \\
4.6 \\
4.9 \\
4.6 \\
4.4\end{array}$ & $\begin{array}{l}0.5 \\
0.6 \\
1.2 \\
1.5 \\
1.2\end{array}$ & $\begin{array}{l}13 \\
13 \\
15 \\
16 \\
18\end{array}$ & $\begin{array}{r}81 \\
86 \\
103 \\
142 \\
118\end{array}$ & $\begin{array}{l}195 \\
215 \\
244 \\
262 \\
236\end{array}$ & $\begin{array}{r}11 \\
12 \\
9 \\
10 \\
0\end{array}$ & $\begin{array}{l}626 \\
698 \\
833 \\
869 \\
772\end{array}$ & $\begin{array}{l}136 \\
155 \\
196 \\
225 \\
205\end{array}$ & $\begin{array}{l}490 \\
543 \\
637 \\
644 \\
567\end{array}$ \\
\hline
\end{tabular}

* Since tyrosine per se was a minimal and relatively constant quantity, blank values following ethereal extraction of the urine never exceeding $50 \mathrm{mgm}$. per day on the diets of cow's milk, the figures in this column represent predominantly $p$-hydroxyphenyllactic acid.

(nitrogen X 6.25). When the diet was changed to cow's milk containing more than 5 grams protein per kgm. per day, the excretion of these substances increased-gradually for the first 4 days following the change, and then abruptly during the next 3 days. In this infant, a maximum level (869 mgm. hydroxyphenyl compounds expressed as tyrosine) was reached on the 9th day after the change of diet. The level of excretion of $p$ hydroxyphenylpyruvic acid was $225 \mathrm{mgm}$. on this day, representing 26 per cent of the total hydroxyphenyl compounds. The remaining $644 \mathrm{mgm}$. represented $p$-hydroxyphenyllactic acid and minimal amounts of tyrosine.

The output of total hydroxyphenyl compounds in the 18 premature infants in whom the defect was studied varied from indeterminable amounts to $1385 \mathrm{mgm}$. per day and for $p$-hydroxyphenylpyruvic acid from traces to $444 \mathrm{mgm}$. per day. In all observations, the output of the hydroxy acid notably exceeded that of the keto acid, the latter comprising less than 40 per cent of the total hydroxyphenyl compounds (expressed as tyrosine) except in two instances ( 44 and 48 per cent), and averaging 29 per cent for the 18 infants.

The content of free phenols in the urine, 90 per cent of which were ether-soluble, varied directly with the concentration of hydroxyphenyl com- pounds as determined by the Millon reaction ( $\mathrm{Ta}$ ble I). Conjugated phenols, on the other hand, were constant within the limits of error of the method. The organic acid content of the urine also paralleled the excretion of hydroxyphenyl compounds.

The amino acid output in the urine never increased significantly, seldom exceeding $20 \mathrm{mgm}$. amino acid nitrogen per kgm. per day and maintaining a practically constant level irrespective of the magnitude of excretion of aromatic organic acids. Similarly, fluctuations in the output of creatine and creatinine were unrelated to the level of excretion of these acids. Total urinary nitrogen varied with the nitrogen intake and was related to the excretion of hydroxyphenyl compounds insofar as the latter were excreted only when the nitrogen intake was relatively high.

Table II and Figure 1 illustrate even more graphically the dependence of the defect on the level of protein, and more especially on the aromatic amino acid intake. The daily intake and output are expressed in terms of body weight (mgm. per kgm.) in the table and in absolute values in the figure (mgm. per 24 hours). This premature infant was fed human and cow's milk of varying protein content and correspondingly varying intakes of phenylalanine and tyrosine (13, 
14) in successive periods. A striking parallelism is noted between the intake of these aromatic amino acids (expressed as tyrosine) and the uri-

TABLE II

Relation of intake to excretion of hydroxyphenyl compounds

\begin{tabular}{|c|c|c|c|c|c|}
\hline \multirow[b]{2}{*}{ Age* } & \multirow[b]{2}{*}{ Period } & \multirow[b]{2}{*}{ Diet } & \multicolumn{2}{|c|}{ Intake } & \multirow{2}{*}{$\begin{array}{c}\text { Hydroxy- } \\
\text { phenyl } \\
\text { compounds } \\
\text { in urine }\end{array}$} \\
\hline & & & Nitrogen & $\begin{array}{c}\text { Tyrosine } \\
\text { plus } \\
\text { phenyl- } \\
\text { alanine }\end{array}$ & \\
\hline days & & & $\begin{array}{l}\text { mgm. per } \\
\text { kgm. per } \\
24 \text { hours }\end{array}$ & $\begin{array}{c}\text { mgm. } \\
\text { tyrosine } \\
\text { per kgm. } \\
\text { per 24 } \\
\text { hourst }\end{array}$ & $\begin{array}{l}\text { mgm. } \\
\text { tyrossine } \\
\text { per kgm. } \\
\text { per \&4 } \\
\text { hours }\end{array}$ \\
\hline $\begin{array}{r}8 \\
9 \\
10\end{array}$ & 1 & $\begin{array}{l}\text { Cow's milk } \\
\text { (high protein) }\end{array}$ & $\begin{array}{l}839 \\
839 \\
839\end{array}$ & $\begin{array}{l}482 \\
482 \\
482\end{array}$ & $\begin{array}{l}255 \\
346 \\
356\end{array}$ \\
\hline $\begin{array}{l}12 \\
13 \\
14 \\
15 \\
16\end{array}$ & 2 & $\begin{array}{l}\text { Cow's milk } \\
\text { (low protein) }\end{array}$ & $\begin{array}{l}412 \\
403 \\
398 \\
385 \\
385\end{array}$ & $\begin{array}{l}237 \\
232 \\
229 \\
221 \\
221\end{array}$ & $\begin{array}{r}189 \\
142 \\
104 \\
87\end{array}$ \\
\hline $\begin{array}{l}17 \\
19 \\
20\end{array}$ & 3 & $\begin{array}{l}\text { Human milk } \\
\text { (low protein) }\end{array}$ & $\begin{array}{l}438 \\
427 \\
424\end{array}$ & $\begin{array}{l}160 \\
156 \\
155\end{array}$ & $\begin{array}{l}7 \\
4\end{array}$ \\
\hline $\begin{array}{l}21 \\
23 \\
24 \\
25 \\
26 \\
27\end{array}$ & 4 & $\begin{array}{l}\text { Cow's milk } \\
\text { (low protein) }\end{array}$ & $\begin{array}{l}458 \\
437 \\
437 \\
428 \\
418 \\
418\end{array}$ & $\begin{array}{l}263 \\
251 \\
251 \\
246 \\
240 \\
240\end{array}$ & $\begin{array}{l}6 \\
5 \\
6 \\
6 \\
8\end{array}$ \\
\hline $\begin{array}{l}28 \\
29 \\
30 \\
31 \\
33 \\
34\end{array}$ & 5 & $\begin{array}{c}\text { Cow's milk } \\
\text { (moderate } \\
\text { protein) }\end{array}$ & $\begin{array}{l}606 \\
597 \\
606 \\
606 \\
593 \\
579\end{array}$ & $\begin{array}{l}349 \\
344 \\
349 \\
349 \\
342 \\
334\end{array}$ & $\begin{array}{r}25 \\
75 \\
166 \\
230 \\
208\end{array}$ \\
\hline $\begin{array}{l}35 \\
36 \\
37\end{array}$ & 6 & $\begin{array}{c}\text { Evaporated } \\
\text { skimmed } \\
\text { human milk } \\
\text { (high protein) }\end{array}$ & $\begin{array}{l}856 \\
690 \\
743\end{array}$ & $\begin{array}{l}314 \\
253 \\
272\end{array}$ & $\begin{array}{l}207 \\
166 \\
107\end{array}$ \\
\hline $\begin{array}{l}38 \\
39 \\
40\end{array}$ & 7 & $\begin{array}{c}\text { Cow's milk } \\
\text { (high protein) }\end{array}$ & $\begin{array}{l}772 \\
760 \\
758\end{array}$ & $\begin{array}{l}445 \\
437 \\
436\end{array}$ & $\begin{array}{l}155 \\
240 \\
309\end{array}$ \\
\hline $\begin{array}{l}42 \\
43\end{array}$ & 8 & $\begin{array}{c}\text { Cow's milk } \\
\text { (high protein) }\end{array}$ & $\begin{array}{l}899 \\
860\end{array}$ & $\begin{array}{l}517 \\
495\end{array}$ & $\begin{array}{l}394 \\
358\end{array}$ \\
\hline
\end{tabular}

* The weight of this infant was $2.20 \mathrm{kgm}$. at the start and $3.26 \mathrm{kgm}$. at the end of observations.

$\dagger$ According to the data of Holt and Howland (13), human milk contains 0.75 per cent lactalbumin and 0.5 per cent 'casein and cow's milk contains 0.5 per cent lactalbumin and 3.0 per cent casein. The amino acid content was calculated from data given by Mitchell and Hamilton (14) for cow's milk protein-lactalbumin: 1.9 per cent tyrosine and 1.2 per cent phenylalanine; casein: 6.5 per cent tyrosine and 3.9 per cent phenylalanine. According to the figures given by Womack and Rose (15) and Bernstein et al (16), the tyrosine content of milk proteins is appreciably lower than the above. Use of the latter figures, however, would not have affected the qualitative interpretation of the results. nary output of hydroxyphenyl compounds (in terms of tyrosine equivalent) in the different periods. Following changes in diet, the lag in excretion previously noted (Table $\mathrm{I}$ ) is also evident in this observation (Periods 2, 5, 6 and 7) and it may afford a possible explanation for the absence of hydroxyphenyl compounds in the urine in $\mathrm{Pe}$ riod 4 when the diet was changed from human (Period 3) to cow's milk of similar protein (2.7 grams per $\mathrm{kgm}$.) but higher aromatic amino acid content. It should be further noted that in Period 6, when the diet consisted of evaporated skimmed human milk of higher protein ( 4.8 grams per kgm.) but of similar aromatic amino acid content, the excretion of intermediary metabolites persisted throughout the period although in progressively reduced amounts. This observation, not conclusive in itself because of the brevity of the period, ${ }^{6}$ suggests that the defect is directly related to the level of the aromatic amino acid intake, whether the dietary protein be of human or bovine origin, a suggestion which is supported by the feeding observations with pure amino acids which follow.

Ingestion of phenylalanine and tyrosine. Following prolonged fore-periods of constant diet of cow's milk, 8 premature infants were given either 1 -tyrosine, or $d, 1$-phenylalanine in a single dose varying from 0.23 to 2.00 grams per $\mathrm{kgm}$. The results are summarized in Table III.

The ingestion of either of these aromatic amino acids resulted in the prompt appearance of intermediary metabolites, when absent in the foreperiods, and in their augmented excretion, when previously present. The peak excretion was attained in some infants in the first 24 hours following ingestion; in other infants it was delayed for 48 hours or longer. Furthermore, the heightened level of excretion persisted in some infants throughout the period of study; in others it was transient, returning to the initial level within 2 to 3 days after ingestion. Finally, the maximal level

- This period was curtailed because of the development of diarrhea which promptly subsided when the diet was changed to cow's milk (Period 7).

7 The possibility that human milk contained accessory factors capable of ameliorating the metabolic anomaly was excluded by experiments in vitamin C-deficient guinea pigs fed unboiled human milk (17), as well as by the results obtained in Period 6 of this observation. 


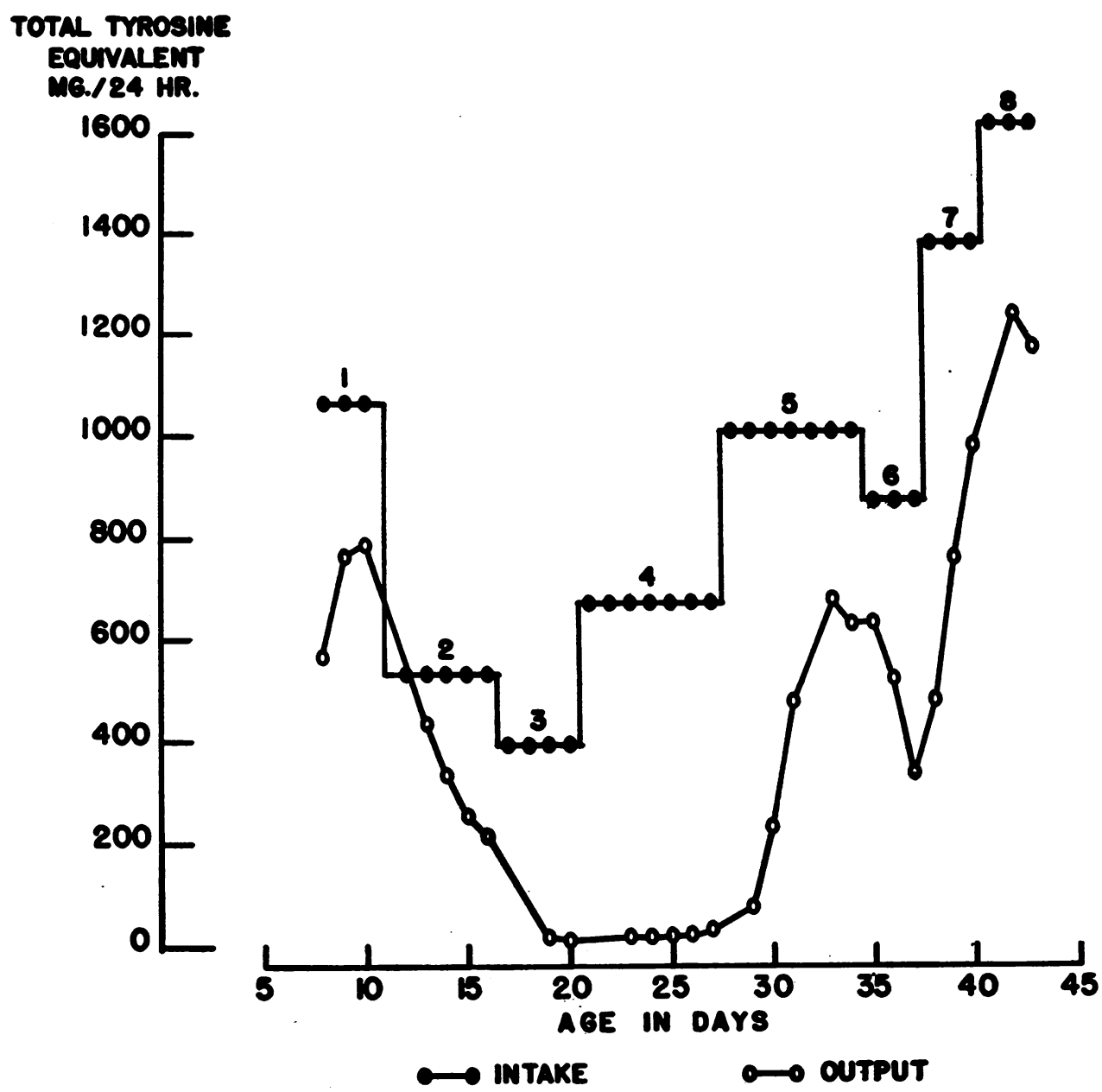

Fig. 1. Effect of Variations in the Intake of Tyrosine and Phenylalanine (Expressed as Tyrosine) on the Excretion of Total Hydroxyphenyl Compounds

of excretion was apparently not solely a function of the amount of amino acid administered. These differences in response of individual infants probably depended on the degree of vitamin $C$ saturation of the tissues (18).

The fact that the urinary output of hydroxyphenyl compounds reached equally high levels in the feeding observations with phenylalanine as with tyrosine suggests that the normal growing human organism can oxidize the phenyl ring of phenylalanine to $p$-hydroxyphenyl derivatives, a conclusion already shown for animals by feeding (19) and liver perfusion (20) experiments.

It is interesting to mention that the administration of phenylalanine resulted in an increased output not only of hydroxyphenyl derivatives but also of phenylpyruvic acid, whereas the converse was not demonstrable; e.g., the administration of tyrosine augmented the output of phenolic derivatives without appreciably affecting the output of phenylpyruvic acid. Thus infant F. J. L. (Table III) excreted $104 \mathrm{mgm}$. phenylpyruvic acid (21) in 20 hours after the ingestion of 2.0 grams phenylalanine per kgm., but showed no appreciable excretion of this acid after the ingestion of tyrosine. This observation is in accord with expectation since phenylalanine, in contrast to tyrosine, is an essential amino acid (15) and the oxidation of phenylalanine to tyrosine is probably a biologically irreversible process (19).

The ingestion by these infants of other amino acids including glycine, methionine and the aromatic amino acid, tryptophane, in comparable or even larger dosage, failed to provoke the appear- 
TABLE III

Effect of ingestion of tyrosine and phenylalanine in premature infants

\begin{tabular}{|c|c|c|c|c|c|c|c|c|c|}
\hline \multirow[t]{2}{*}{ Subject } & \multicolumn{2}{|c|}{ Dose of amino acid } & \multirow{2}{*}{\multicolumn{2}{|c|}{\begin{tabular}{c|c}
$\begin{array}{c}\text { Hydroxy- } \\
\text { phenyl } \\
\text { compounds } \\
\text { expressed } \\
\text { as tyrosine }\end{array}$ & $\begin{array}{c}\text { p-Hydroxy- } \\
\text { phenyl- } \\
\text { pyruvic acid }\end{array}$ \\
mgm. per 24 hours in urine
\end{tabular}}} & \multirow[t]{2}{*}{ Subject } & \multicolumn{2}{|c|}{ Dose of amino acid } & \multirow{2}{*}{$\begin{array}{l}\text { Hydroxy- } \\
\text { phenyl } \\
\text { compounds } \\
\text { expressed } \\
\text { as tyrosine }\end{array}$} & \multirow{2}{*}{$\begin{array}{c}\text { p-Hydroxy- } \\
\text { phenyl- } \\
\text { pyruvic acid }\end{array}$} \\
\hline & $\underset{\text { grams }}{\text { total }}$ & $\begin{array}{c}\text { grams per } \\
\text { kgm. }\end{array}$ & & & & $\underset{\text { grams }}{\text { total }}$ & $\begin{array}{c}\text { grams per } \\
\text { kgm. }\end{array}$ & & \\
\hline \multicolumn{5}{|c|}{$l$-TYROSINE } & \multicolumn{5}{|c|}{$d, l$-PHENYLALANINE } \\
\hline F. $Z$. & 1.00 & 0.45 & $\begin{array}{r}30 \\
218 \\
464\end{array}$ & $\begin{array}{r}12 \\
112 \\
216\end{array}$ & F. J. L. & 1.37 & 0.50 & $\begin{array}{l}684 \\
688 \\
842 \\
685\end{array}$ & $\begin{array}{l}140 \\
151 \\
178\end{array}$ \\
\hline P. J. A. & 2.50 & 1.00 & $\begin{array}{r}973 \\
1277 \\
1030\end{array}$ & $\begin{array}{l}348 \\
388 \\
337\end{array}$ & & 5.78 & $2.00^{*}$ & $\begin{array}{r}083 \\
627 \\
899 \\
1081\end{array}$ & $\begin{array}{l}128 \\
217 \\
249\end{array}$ \\
\hline H. C. A. & 2.60 & 1.00 & $\begin{array}{r}905 \\
1184 \\
1408 \\
1071\end{array}$ & $\begin{array}{l}203 \\
386 \\
435 \\
349\end{array}$ & W. B. & 0.64 & 0.23 & $\begin{array}{r}16 \\
337 \\
688 \\
712 \\
831\end{array}$ & $\begin{array}{r}3 \\
123 \\
204 \\
210 \\
256\end{array}$ \\
\hline F. J. L. & 1.19 & 0.50 & $\begin{array}{l}498 \\
610 \\
695 \\
592\end{array}$ & $\begin{array}{r}98 \\
124 \\
116 \\
118\end{array}$ & R. S. & 2.21 & 0.82 & $\begin{array}{r}28 \\
589 \\
839\end{array}$ & $\begin{array}{r}13 \\
373 \\
396\end{array}$ \\
\hline G. C. & 0.51 & 0.24 & $\begin{array}{l}401 \\
534 \\
459 \\
341\end{array}$ & $\begin{array}{r}108 \\
153 \\
143 \\
86\end{array}$ & & & & & \\
\hline
\end{tabular}

* On this day $104 \mathrm{mgm}$. phenylpyruvic acid were excreted in the urine.

ance or raise the urinary excretion of these intermediary products. The observation with tryptophane was of particular interest since no defect in its metabolism was demonstrated. The ingestion of 2.25 grams ( 1.0 gram per kgm.) of tryptophane by one infant (H. C. A.) was associated neither with an increased excretion of total hydroxyphenyl compounds or $p$-hydroxyphenylpyruvic acid nor with the appearance in the urine of indole, skatole (22) or kynurenic acid (23). In contrast with the lack of response to tryptophane, the ingestion of tyrosine in the same dosage by this infant a few days later (Table III) notably augmented the excretion of hydroxyphenyl compounds.

The excretion of tryptophane per se in the urine (7) amounted to $300 \mathrm{mgm}$., or 13 per cent of the ingested dose. The output of amino acid nitrogen, as determined, increased $43 \mathrm{mgm}$. in the 24 hours following ingestion, receding to the foreperiod level during the succeeding 24 hours. ${ }^{8}$

8 Although the output of amino acid nitrogen was never increased significantly in premature infants receiving
COMMENT

Tyrosine and phenylalanine are among the few aromatic substances that ordinarily undergo complete oxidation in the human body. Aberrations in their metabolism are rare, the only well-known

cow's milk (20 mgm. or less per kgm. per day), or rarely after the ingestion of 1-tyrosine, it did show an almost invariable tendency to rise following the ingestion not only of 1-trytophane but also of $d, 1$-methionine and $d, 1$-phenylalanine. In one observation with $d, 1$-methionine, the increase in amino acid nitrogen excretion accounted for 27 per cent of the ingested dose of 1.0 gram per $\mathrm{kgm}$. The increase in amino acid content of the urine in 6 of 7 observations with $d, 1$-phenylalanine represented from 19 to 42 per cent of the ingested dose, the average of the 7 observations being 22.4 per cent. In 3 observations with glycine, the extra amino acid in the urine represented 4 to 12 per cent (average 7.5 per cent) of the ingested dose. A significant augmentation in excretion of amino acid nitrogen occurred, with one exception (1-tryptophane) following the ingestion of synthetic amino acids ( $d, 1$-methionine, and $d, 1$-phenylalanine), suggesting that the unnatural enantiomorph present might have been a contributing factor (24). 
instances being the congenital defects, alkaptonuria and phenylpyruvic oligophrenia (25). Even the artificial induction of defects entails considerable difficulty. Abderhalden (26) claimed to have isolated small amounts of homogentisic acid after the oral administration of $\mathbf{5 0}$ grams of tyrosine to a normal man but he was unable to produce alkaptonuria in rabbits and dogs. Papageorge and Lewis (27) also failed to produce alkaptonuria in rabbits but, when phenylalanine was fed to rats in amounts greater than 0.3 gram per 100 grams rat, alkaptonuria appeared within 2 to 29 days. Recent work by Sealock and Silberstein (28) has shown that alkaptonuria is readily produced in vitamin C-deficient guinea pigs by the ingestion of as little as 0.15 gram tyrosine per 100 grams animal per day. They obtained similar results in 2 normal human subjects on a vitamin C-deficient diet. The defect in the metabolism of tyrosine and phenylalanine exhibited by premature infants is not alkaptonuria since they never excreted homogentisic acid in significant amounts.

The path of the metabolism of tyrosine and phenylalanine is not definitely known but the available evidence indicates that $p$-hydroxyphenylpyruvic acid may be an obligatory intermediate (14). Kotake and his coworkers (3) found that rabbits excrete $p$-hydroxyphenylpyruvic acid in the urine after large doses of tyrosine and also $p$ hydroxyphenyllactic acid if 1-tyrosine is ingested. When large amounts of phenylalanine were fed, phenylpyruvic acid was the principal intermediary product appearing in the urine but after several days of continuous administration of the amino acid, $p$-hydroxyphenylpyruvic acid was also excreted.

Lewis and his coworkers (4a) found phenylpyruvic acid in the urine of rabbits after feeding phenylalanine but the intermediary metabolite following tyrosine was not $p$-hydroxyphenylpyruvic acid but, presumably, $p$-hydroxyphenyllactic acid. Sealock and Silberstein (29) later demonstrated that vitamin C-deficient guinea pigs excrete $p$-hydroxyphenylpyruvic and $p$-hydroxyphenyllactic acids in addition to homogentisic acid after the administration of either tyrosine or phenylalanine.

A single instance of the spontaneous excretion of $p$-hydroxyphenylpyruvic acid in a human was reported by Medes (5). She applied the term "tyrosinosis" to this anomaly which was characterized by the continuous excretion of about 1.6 grams $p$-hydroxyphenylpyruvic acid of endogenous origin, the excretion rising with ingestion of $p$ hydroxyphenylpyruvic acid, tyrosine or proteins. Only when the urinary output of p-hydroxyphenylpyruvic acid reached the high level of approximately 3 grams per day was tyrosine also excreted. p-Hydroxyphenyllactic acid was excreted still later after the subject had been on a high protein diet for several days or had received 10 grams of tyrosine per day for at least 2 days. Homogentisic acid was not excreted.

The defect in metabolism of tyrosine and phenylalanine observed in premature infants differs from the aforementioned defects, both spontaneous and artificially produced, in that more $p$-hydroxyphenyllactic acid than $p$-hydroxyphenylpyruvic acid was excreted and that significant amounts of homogentisic acid have not been found in their urine. It is, of course, conceivable that the failure of these infants to excrete the latter acid may have been due to the relatively low intake of its precursors. Papageorge and Lewis (27) found an intake of 0.3 gram phenylalanine per 100 grams rat per day necessary to produce it in rats. In Sealock's experiments (29) with scorbutic guinea pigs, 0.15 to 0.33 gram of tyrosine or phenylalanine per 100 grams of body weight provoked alkaptonuria. The diets fed to premature infants averaged 5 grams protein per $\mathrm{kgm}$. per day. Using the previously quoted published data, this average intake may be calculated to contain the equivalent of about 0.5 gram of total tyrosine (tyrosine plus phenylalanine expressed as tyrosine) per kgm. per day. This level of ingestion is lower than the animal intake ( 1.5 to 3.3 grams per $\mathrm{kgm}$.) and it is possible that with prolonged addition of extra tyrosine or phenylalanine to the diet, these infants might also have shown alkaptonuria. Single doses of as much as 2 grams per $\mathrm{kgm}$. of either tyrosine or phenylalanine did not lead to the excretion of significant amounts of homogentisic acid.

The clinical significance of these findings in infants and the circumstances under which the de- 
fect occurs and disappears will be discussed in the succeeding paper.

\section{SUM MARY}

Premature infants receiving diets of relatively high protein content ( 5 grams or more per $\mathrm{kgm}$. per day) exhibit a spontaneous defect in their metabolism of tyrosine and phenylalanine. The defect is manifested by the excretion of $1-p$ hydroxyphenyllactic and $p$-hydroxyphenylpyruvic acids in the urine. It may be accentuated by feeding these amino acids in pure form.

\section{BIBLIOGRAPHY}

1. Benedict, S. R., and Behre, J. A., Some applications of a new reaction for creatinine. J. Biol. Chem., 1936, 114, 515.

2. Folin, O., A colorimetric determination of the aminoacid nitrogen in normal urine. J. Biol. Chem., 1922, 51, 393.

3a. Kotake, Y., Matsuoka, Z., and Okagawa, M., Ueber die Desaminierung des Tyrosins im tierischen Organismus. Ztschr. physiol. Chem., 1922, 122, 166.

b. Kotake, Y., and Okagawa, M., Ueber die Ausscheidung der Oxyphenylmilchsäure bei Tyrosinfütterung an Kaninchen. Ibid, 1922, 122, 201.

4a. Shambaugh, N. F., Lewis, H. B., and Tourtelotte, D., Comparative studies of the metabolism of the amino acids. IV. Phenylalanine and tyrosine. $\mathrm{J}$. Biol. Chem., 1931, 92, 499.

b. Chandler, J. P., and Lewis, H. B., Comparative studies of the amino acids. V. The oxidation of phenylalanine and phenylpyruvic acid in the organism of the rabbit. Ibid, 1932, 96, 619.

5. Medes, G., A new error of tyrosine metabolism: tyrosinosis. The intermediary metabolism of tyrosine and phenylalanine. Biochem. J., 1932, 26, 917.

6a. Block, R. J., and Bolling, D., Chemical and metabolic studies on phenylalanine. I. The nitration of phenylalanine. J. Biol. Chem., 1939, 129, 1.

b. Block, R. J., Jervis, G. A., Bolling, D., and Webb, M., Chemical and metabolic studies on phenylalanine. III. The amino acid content of tissue proteins of normal and phenylpyruvic oligophrenic individuals. A note on the estimation of phenylalanine. Ibid, 1940, 134, 567.

7. Folin, O., and Ciocalteu, V., On tyrosine and tryptophane determinations in proteins. J. Biol. Chem., 1927, 73, 627.

8. Gaebler, O. H., Further studies of blood creatinine. J. Biol. Chem., 1930, 89, 451.

9. Herbst, D., and Shemin, R. M., $d, 1-\beta$-Phenylalanine, in Organic Syntheses, 1939, 19, 67.
10. Van Slyke, D. D., and Palmer, W. W., Studies of acidosis. XVI. The titration of organic acids in urine. J. Biol. Chem., 1920, 41, 567.

11a. Peters, J. P., and Van Slyke, D. D., Quantitative Clinical Chemistry, Vol. II, Methods. Williams and Wilkins Co., Baltimore, 1932, p. 602.

b. Marples, E., and Levine, S. Z., Creatinuria in infancy and childhood. I. Normal variations; creatine tolerance tests and the effect of aminoacetic acid in normal infants. Amer. J. Dis. Child., 1936, 51, 30.

12. Folin, O., and Denis, W., A colorimetric method for the determination of phenols (and phenol derivatives) in urine. J. Biol. Chem., 1915, 22, 305.

13. Holt, L. E., and Howland, J., Diseases of infancy and childhood, eleventh edition, revised by $L$. E. Holt, Jr. and R. McIntosh. Appleton, New York, 19.39, p. 194.

14. Mitchell, H. H., and Hamilton, T. S., The biochemistry of the amino acids. Chemical Catalog Co., New York, 1929, p. 191.

15. Womach, M., and Rose, W. C., Feeding experiments with mixtures of highly purified amino acids. VI. The relation of phenylalanine and tyrosine to growth. J. Biol. Chem., 1934, 107, 449.

16. Bernstein, S. S., Beach, E. F., and Hoffman, O., The amino acid composition of the proteins of cow and human milk. Presented at the meeting of the Society for Pediatric Research at Skytop, Pa., on April 26, 1939.

17. Dann, M., Unpublished data.

18. Levine, S. Z., Marples, E., and Gordon, H. H., A defect in the metabolism of aromatic amino acids in premature infants: the role of vitamin C. Science, 1939, 90, 620.

19. Moss, A. R., and Schoenheimer, R., The conversion of phenylalanine to tyrosine in normal rats. $\mathrm{J}$. Biol. Chem., 1940, 135, 415.

20. Embden, G., and Baldes, K., Ueber den Abbau des Phenylalanins im tierischen Organismus. Biochem. Ztschr., 1913, 55, 301.

21. Jervis, G. A., Block, R. J., Bolling, D., and Kanze, E., Chemical and metabolic studies on phenylalanine. II. The phenylalanine content of the blood and spinal fluid in phenylpyruvic oligophrenia. J. Biol. Chem., 1940, 134, 105.

22. Hawk, P. B., and Bergeim, O., Practical Physiological Chemistry. Blakiston, Philadelphia, 1937, 11th Ed., p. 364.

23. Berg, C. P., Tryptophane metabolism. I. The production of kynurenic acid from tryptophane derivatives. J. Biol. Chem., 1931, 91, 513.

24a. du Vigneaud, V., and others, A study of the inversion of $d$-phenylaminobutyric acid and the acetylation of 1-phenylaminobutyric acid by means of the isotopes of nitrogen and hydrogen. J. Biol. Chem., 1939, 131, 273. 
b. Steele, J. M., Dobriner, K., and Galdston, M., Studies of homogentisic acid production in a case of alkaptonuria. J. Clin. Invest., 1940, 19, 792.

25a. Fölling, A., Ueber Ausscheidung von Phenylbrenztraubensäure in den Harn als Stoff wechselanomalie in Verbindung mit Imbezillität. Ztschr. physiol. Chem., 1934, 227, 169.

b. Penrose, L., and Quastel, J. H., Metabolic studies in phenylketonuria. Biochem. J., 1937, 31, 266.

c. Jervis, G. A., Metabolic investigations on a case of phenylpyruvic oligophrenia. J. Biol. Chem., 1938, 126, 305.

26. Abderhalden, E., Bildung von Homogentisinsäure nach Aufnahme grosser Mengen von 1-Tyrosin per os. Ztschr. physiol. Chem., 1912, 77, 454.

27. Papageorge, E., and Lewis, H. B., Comparative studies of the metabolism of amino acids. VII. Experimental alcaptonuria in the white rat. J. Biol. Chem., 1938, 123, 211.

28. Sealock, R. R., and Silberstein, H. E., Control of experimental alcaptonuria by means of vitamin $\mathrm{C}$. Science, 1939, 90, 517.

29. Sealock, R. R., and Silberstein, H. E., The excretion of homogentisic acid and other tyrosine metabolites by the vitamin $\mathrm{C}$-deficient guinea pig. J. Biol. Chem., 1940, 135, 251. 